Harry Potter and the Fixation Requirement: An Attempt at Applying the U.S. Copyright Act of 1976 to J.K. Rowling's World of Witchcraft and Wizardry

Yvette Joy Liebesman

Georgetown University Law Center, yvettejoy@gmail.com

This paper can be downloaded free of charge from:

http://scholarship.law.georgetown.edu/spps_papers/2 


\title{
Harry Potter and the Fixation Requirement: An Attempt at Applying the U.S. Copyright Act of 1976 to J. K. Rowling's World of Witcheraft and Wizardry
}

\author{
Yvette Joy Liebesman ${ }^{\dagger}$ \\ "Any sufficiently advanced technology is indistinguishable from magic." \\ Arthur C. Clarke
}

\section{$\underline{\text { Introduction }}$}

In the Harry Potter universe, images in photographs and paintings move about ${ }^{1}$-an issue of the wizards' newspaper, the Daily Prophet, shows the Weasley family in a "moving photograph... waiving furiously" at the camera while enjoying their vacation at the pyramids in Egypt ${ }^{2}$ the Fat Lady $^{3}$ in a painting at the Gryffindor tower entrance speaks to passersby, is sometimes asleep, other times awake, and has gone missing; ${ }^{4}$ a photograph of Albus Dumbledore, the headmaster at Hogwarts School of Witchcraft and Wizardry, leaves his trading card. ${ }^{5}$ Supposing these items exist, one could posit whether they qualify for copyright protection under current United States law; that is, whether works such as the paintings that hang at

\footnotetext{
${ }^{\dagger}$ A.B., Georgetown University; B.A., Rutgers University; M.S., University of California, San Diego (Scripps Institution of Oceanography); J.D., Georgetown University Law Center. Email: yjl@georgetown.edu.

${ }^{1}$ We first become acquainted with this phenomena when Harry is traveling to Hogwarts. See J.K. RowLING, HARRY POTTER AND THE SORCERER's STONE 103 (Scholastic 1999) [hereinafter SORCERER's STONE]. See also infra note 46 and accompanying text.

${ }^{2}$ J.K. Rowling, HARry Potter AND the Prisoner OF AZKABAn 8 (Scholastic 1999) [hereinafter AZKABAN].

${ }^{3}$ See, e.g., SORCERER's StONE at 129. This is how she is referred to in the HARRY POTTER books. No insult towards people who consider themselves to be overweight is implied or intended.

${ }^{4}$ See, e.g., AZKABAN at 160 . The Fat Lady was missing from her painting and the canvass slashed.

${ }^{5}$ SORCERER'S STONE at 103.
} 
Hogwarts meet the subject matter and fixation requirements under the Copyright Act of 1976 ("the Act").

To ascertain whether these works are copyrightable, this essay first focuses on the development of copyright law in the United States, how it has been expanded and adapted to emerging technologies, and the fixation requirement under the Act. It then discusses how magic could be considered a new technology covered by the Act. The Act is then applied to the magically-animated persons in paintings and photographs in the Harry Potter universe to determine whether they could be protectable works.

\section{Fixating on Copyrightability}

"The Fat Lady had vanished from her portrait. . ."6

\section{a. THE EVER-GROWING SUBJECT MATTER OF COPYRIGHT}

"The history of copyright law has been one of gradual expansion in the types of works accorded protection."7 The first "Copyright Act of 1790 granted protection to the author ... of any map, chart, or book." 8 As noted by William F. Patry in his treatise on copyright law, in the 1789 Act, "the term 'book' was not defined, but was generally construed broadly"' to include

\footnotetext{
${ }^{6}$ AZKABAN at 160 .

${ }^{7}$ H.R. Rep. No. 94-1476 at 51.

${ }^{8}$ William F. PATRY, COPYRIGHT LAW AND PRACTICE 30 (1994). For additional reading on the history of United States copyright legislation, see Craig Joyce, “A Curious Chapter in the History of Judicature”: Wheaton v. Peters and the Rest of the Story (of Copyright in the New Republic) 42 Hous. L. REV. 325 (2005).

${ }^{9}$ PATRY, supra note 8 , at 30 . 
“every character of publication; whether a volume, pamphlet, newspaper article, calendar, or catalogue."10 Under the 1790 Act, the courts also interpreted "book" to include "a volume made up of several sheets bound together; it may be printed only on one sheet, as the words of a song or the music accompanying it."11

The 1831 Act expanded the list of works covered and provided exclusive rights for "printing, reprinting, publishing, and vending such book or books, map, chart, musical composition, print, cut, or engraving, in whole or in part. ..."12 While it was the first time there was "express protection for musical compositions,"13 the 1831 Act, like the 1790 Act, did not contemplate forms that had yet to be invented, such as recorded music either on rolls for a player-piano, ${ }^{14}$ recorded music, or any other future technology; the list of media eligible for copyright was finite.

At the beginning of the twentieth century, the Supreme Court was confronted with a seminal copyright case involving new technology. ${ }^{15}$ The defendant, the Apollo Company, had transferred a melody from sheet music to a roll of paper with perforations that allowed the tune to be played on a player piano. This new medium was not contemplated by the Copyright Act in

${ }^{10} I d$. at 30-31, citing Brightley v. Littleton, 37 F.103, 104. (C.C.E.D. Pa. 1888).

${ }^{11}$ Id. at 31, citing Clayton v. Stone, 5 F. Cas. 999, 1000 (C.C.S.D.N.Y. 1829) (No. 2,872).

${ }^{12}$ Act of February 3, 1831, 31st Cong., 2d Sess., 4 Stat. 436.

${ }^{13}$ PATRY, supra note 8 , at 39 .

${ }^{14}$ A player piano, also called a "pianola," is a self-playing piano which came into vogue at the beginning of the 20th century. Perforated rolls of paper transposed the notes from a musical composition into a form that was read by the pianola's player mechanism. See The Player Piano Page, found at http://www.pianola.com/ (last accessed Oct. 29, 2005).

${ }^{15}$ White-Smith Music Publishing Co. v. Apollo Co., 209 U.S. 1, 28 S.Ct. 319 (1908).

Draft of 30 April 2006

Preliminary Working Draft — Do Not Cite or Distribute without Consent

Copyright Yvette Joy Liebesman 2006 
effect at the time, ${ }^{16}$ which, like its predecessors, limited the subject matter of copyright to specific forms. ${ }^{17}$ "[P] rior to 1909 , mechanical devices, such as music rolls, discs and records, for the reproduction of sound, were held to be beyond the scope of the copyright laws and not to infringe protected works which they were the means of audibly reproducing."18 In White-Smith Music Publishing Company. v. Apollo Company, ${ }^{19}$ the Supreme Court held that these perforated rolls of paper used in a pianola (a player piano) to play a song did not violate the copyright of the sheet music for that particular tune. ${ }^{20}$ Partially in response to the Supreme Court's holding in White-Smith Music, Congress enacted a major revision to the Copyright Act in $1909,{ }^{21}$ which, while broadening the forms of works that could be protected by copyright, ${ }^{22}$ continued to limit works to technology already in existence. ${ }^{23}$

\section{b. CONTEMPLATING TECHNOLOGIES IN THE COPYRIGHT ACT OF 1976}

The next substantive revision to United States copyright law, the Copyright Act of $1976,{ }^{24}$ adopted several major changes. The two relevant to this discussion are (1) the expansion

\footnotetext{
${ }^{16}$ See Copyright Act of 1831 as amended.

${ }^{17}$ Act of February 3, 1831, 31st Cong., 2d Sess., 4 Stat. 436.

${ }^{18}$ Waring v. WDAS Broadcasting Station, Inc., 327 Pa. 433 (1937). See also White-Smith, 209 U.S. 1.

${ }^{19} 209$ U.S. 1 (1908).

${ }^{20}$ While Apollo dealt with fixation for infringement rather than original protection, it is still a useful example of the previously limited scope of protection.

${ }^{21}$ Ch. 320, 35 Stat. 1075 (1909).

${ }^{22}$ PATRY, supra note 8 , at 58.

${ }^{23} 35$ Stat. 1075-76 (1909).

${ }^{24} 17$ U.S.C. § 102(a) (2004).
}

Draft of 30 April 2006 Preliminary Working Draft — Do Not Cite or Distribute without Consent Copyright Yvette Joy Liebesman 2006 
of subject matter to include future technologies; and (2) the change from protection through the observation of formalities to a system where protection began at the time the work was "fixed into a tangible medium of expression . .."25 Under the current Act, ${ }^{26}$ a work does not attain copyright protection if it is considered to be in an area of existing subject matter that the Act does not propose to protect, or it is a transient reproduction. ${ }^{27}$

The 1976 Act provided for an indefinite expansion of the subject matter covered-for the first time, Congress contemplated of technologies not in existence at the time of the law's enactment. ${ }^{28}$ When choosing to expand the subject matter of copyright, Congress noted that .. . scientific discoveries and technological developments have made possible new forms of creative expression that never existed before. In some of these cases the new expressive forms-- electronic music, filmstrips, and computer programs, for example- could be regarded as an extension of copyrightable subject matter Congress had already intended to protect, and were thus considered copyrightable from the outset without the need of new legislation. In other cases, such as photographs, sound recordings, and motion pictures, statutory enactment was deemed necessary to give them full recognition as copyrightable works. ${ }^{29}$

Under the 1976 Act, "copyright protection subsists. . . in original works of authorship fixed in any tangible medium of expression, now known or later developed, from which they can be perceived, reproduced, or otherwise communicated, either directly or with the aid of a

\footnotetext{
${ }^{25} I d$.

${ }^{26}$ This is in addition to the requirement of originality. 17 U.S.C. $\S 101$ (2004) (“Copyright protection subsists ... in original works of authorship ...”) ; see also H.R. Rep. No. 94-1476, 94th Cong., 2d Sess. 52-53 (1976), reprinted in 1976 U.S.C.C.A.N. 5659, 5664 [hereinafter H.R. Rep. No. 94-1476]. There are "two fundamental criteria of copyright protection- originality and fixation in tangible form." Id. It is assumed for purposes of this paper that works discussed herein meet the originality requirement for copyright protection

${ }^{27}$ H.R. Rep. No. 94-1476, at 52.

${ }^{28} I d$. at 51 .

${ }^{29} I d$.
} 
machine or device."30 The Act was designed to expand with technology, and while Congress may not have had works created by magic specifically in mind, the legislative history indicates that it did not want to limit protection to current technologies.

Authors are continually finding new ways of expressing themselves, but it is impossible to foresee the forms that these new expressive methods will take. The bill does not intend either to freeze the scope of copyrightable subject matter at the present stage of communications technology or to allow unlimited expansion into areas completely outside the present congressional intent. Section 102 [of the Act] implies neither that that subject matter is unlimited nor that new forms of expression within that general area of subject matter would necessarily be unprotected. $^{31}$

Congress also noted that historically, expansion of copyright to forms of expression were gradually expanded as they came "to be recognized as creative and worthy of protection." 32 For example, the United State's first copyright statute in 1790 recognized "only maps, charts, and books;" it was only later statutes that addressed "major forms of expression such as music, drama, and works of art." 33 When enacting the current Act, Congress chose broad language, "to avoid the artificial and largely unjustifiable distinctions derived from cases"34 — statutory copyrightability was no longer dependant "upon the form or medium in which the work is fixed. ${ }^{\prime 35}$ Yet despite the broad range of protectable subject matter, there were other areas of existing subject matter that the Act did not propose to protect at the time. ${ }^{36}$

\footnotetext{
${ }^{30} 17$ U.S.C. $\S 102(a)(2004)$.

${ }^{31}$ H.R. Rep. No. 94-1476, at 51-52.

${ }^{32} I d$.

${ }^{33} I d$. (internal quotations omitted).

${ }^{34} I d$.

${ }^{35} I d$.
}

Under the [Act] it makes no difference what the form, manner, or medium of fixation may be - whether it is in words, numbers, notes, sounds, pictures, or any other graphic or symbolic indicia, whether embodied 


\section{c. FIXATION AND THE COPYRIGHT ACT OF 1976}

A second major change in the 1976 Act to the United States copyright regime was the replacement of protection through formalities with protection at the time of fixation. Prior to the 1976 Act, the recognition of copyright protection was dictated by formalities. Determination of copyright depended solely on whether the party holding a copyright had complied with the terms of the Act in effect at the time the work was created, ${ }^{37}$ such as registration prior to publication, the publication of the work within a specific time period, submission of copies to the Library of Congress, and proper copyright notice on the work. ${ }^{38}$ This also implied a requirement that the work be fixed in a tangible medium of expression as a basic condition of copyright protection. ${ }^{39}$ In the 1976 Act, Congress maintained the fixation requirement, but removed most of the formalities. $^{40}$

in a physical object in written, printed, photographic, sculptural, punched, magnetic, or any other stable form, and whether it is capable of perception directly or by means of any machine or device now known or later developed.

Id. at 52-53.

${ }^{36} I d$. at $51-52$.

${ }^{37}$ Wheaton v. Peters, 33 U.S. 591 (1834).

${ }^{38}$ See Craig Joyce, MARshall LeAfFer, ET. AL, Copyright LaW 77 (6th Ed. 2003); see also L. Ray Patterson and Craig Joyce, Copyright in 1791: An Essay Concerning the Founders' View of the Copyright Power Granted to Congress in Article I, Section 8, Clause 8 of the U.S. Constitution, 52 Emory L.J. 909 (2003). For example, formalities of the 1790 Act

required that a printed copy of the title be deposited in the clerk's office of the district court where the author or other copyright proprietor resided. Within two months from the date thereof, a copy of the record was to be published in one or more newspapers printed in the United States, for the space of four weeks. . . within six months of publication, [the author was] to deliver a copy of the work to the Secretary of State.

Id. at 941 .

${ }^{39}$ H.R. Rep. No. 94-1476, at 52-53.

${ }^{40} I d$. at 52. All remaining formalities were removed in the 1989 amendments to the Act.

Draft of 30 April 2006

Preliminary Working Draft — Do Not Cite or Distribute without Consent

Copyright Yvette Joy Liebesman 2006 
Congress intended for 'fixation' to include when "the program content is transmitted live to the public while being recorded at the same time. ..."41 "The fixation requirement ... [did] not require that the work be written down or recorded somewhere exactly as it is perceived by the human eye," ${ }^{, 42}$ such as music transposed onto the perforated rolls used in a pianola, or a recording on a cassette tape, vinyl record, or compact disk. It sought to limit fixation by "exclud[ing] from the concept purely evanescent or transient reproductions such as those projected briefly on a screen, shown electronically on a television or other cathode ray tube, or captured momentarily in the "memory' of a computer." 43 The antagonist for this issue was the desire to create a mechanism by which live broadcasts, such as televised football games, could meet the fixation requirement, ${ }^{44}$ while maintaining a bar on federal copyright protection for unrecorded performances.

While originality is a factual determination based on the actual work, ${ }^{45}$ fixation is based on the medium, whether the work is fixed in a tangible form. It could be argued that we must know what the work is (that is, understanding and defining the technology embodying it) in order for it to be copyrightable subject matter. We could say that if we do not really know what the work is, then we cannot determine whether it falls within the protections of the Act. This is not true. The Copyright Act clearly contemplated a future technology without regard to our

\footnotetext{
${ }^{41} I d$.

${ }^{42}$ Midway Manufacturing Co. v. Artic Int'1, Inc., 547 F. Supp. 999 (N.D. Ill. 1983), aff'd 704 F.2d 1009 (7th Cir. 1982), cert. denied, 464 U.S. 823 (1983).

${ }^{43}$ H.R. Rep. No. 94-1476 at 53.

${ }^{44} I d$. at 52 .

${ }^{45}$ It is assumed for purposes of this essay that all magically created works discussed herein meet the originality requirement for copyright protection.
}

Draft of 30 April 2006

Preliminary Working Draft — Do Not Cite or Distribute without Consent

Copyright Yvette Joy Liebesman 2006 
understanding of the technology. What the work "is" is irrelevant with respect to fixation in a tangible medium.

\section{Harry Potter and the Copyright Act of 1976}

"Harry turned the card back over and saw, to his astonishment, that

Dumbledore's face had disappeared. 'He's gone!' 'Well, you can't expect him to

hand around all day, 'said Ron. "46

\section{a. IS A MAGICALLY-ANIMATED PAINTING COPYRIGHTABLE SUBJECT MATTER?}

Suppose an artist has painted a work of art which depicts a man sitting at a desk. Through some unknown technology [or perhaps through magic], the man in the painting is then given the ability to speak, move, and think. For the purpose of this hypothetical, he is not alive, merely the animation of a character created by the artist. He is, however, for all intents and purposes, an independently moving and thinking creature who resides in the world depicted in the painting. The magical painting may be considered a window into a reality created and controlled by the artist. The man may stand up and leave the room, speak to other people in the painting, and verbally interact with those viewing the work from the "outside." However, he cannot change his clothes, leave the confines of the painted world, or act in a manner not contemplated by the artist. The question arises as to whether such a man, or the painting itself, would be subject matter covered under the Act. ${ }^{47}$

\footnotetext{
${ }^{46}$ SORCERER's STONE at 103.

${ }^{47} 17$ U.S.C. § 102(a) (2004).
} 
First, it could be argued that the magic painting in our example falls into a combination of three categories of copyrightable subject matter: (1) a "literary work[];", (2) a "pictorial, graphic, and sculpture work[];",49 and (3) a "dramatic work,"50 "motion picture" "audiovisual work." 52 Irregardless of magic, the work was painted by an artist, on a canvas. Were it not for the magical animation, the painting would require no special category to invoke protection under the Act; it can be argued that the man's ability to move and speak does not render the painting unprotectable under the Act.

Second, the phrase "now known or later developed"53 of Section 102(a) could include, as allowable subject matter of copyright, works of art containing moving and speaking persons and animals, either by magic or other means. Congress did not discriminate against magic when contemplating this section, and there is no explicit prohibition against having works created by magic as allowable subject matter. Congress clearly wanted the Act to apply for technologies yet to be conceived. We cannot say that the Copyright Act cannot answer the question of whether

\footnotetext{
${ }^{48} \S 102(\mathrm{a})(1)$. "Literary works are works, other than audiovisual works, expressed in words, numbers, or other verbal or numerical symbols or indicia, regardless of the nature of the material objects, such as books, periodicals, manuscripts, phonorecords, film, tapes, disks, or cards, in which they are embodied.” $§ 101$ (2004) (internal quotations omitted).

${ }^{49} \S 102(a)(5)$. "Pictorial, graphic, and sculptural works include two-dimensional and three-dimensional works of fine, graphic, and applied art, photographs, prints and art reproductions, maps, globes, charts, diagrams, models, and technical drawings, including architectural plans." $§ 101$ (internal quotation omitted).

${ }^{50} \S 102(a)(3)(2004)$.

${ }^{51} \S 102(a)(6)(2004)$. "Motion pictures are audiovisual works consisting of related images which, when shown in succession, impart an impression of motion, together with accompanying sounds, if any." §101 (internal quotation omitted).

${ }^{52} \S 101$. "Audiovisual works are works that consist of a series of related images which are intrinsically intended to be shown by the use of machines or devices such as projectors, viewers, or electronic equipment, together with accompanying sounds, if any, regardless of the nature of the material objects, such as films, or tapes, in which the works are embodies. $I d$. (internal quotation omitted).

${ }^{53} \S 102(a)$.
} 
moving subjects in the photographs and paintings are fixed merely because it does not contemplate a world in which there is magic - how things work is a matter for Patent law, not Copyright law. Magic was not an existing technology, and magically-animated paintings were not existing subject matter in 1976 that Congress chose not to protect. There is nothing in the legislative history to indicate Congress contemplated the physical embodiments of works created or animated through magic. Thus, magically-animated paintings could be construed to be protectable subject matter under the Act.

\section{b. Substantiating FiXation for a Painting Containing Moving and SPEAKING People}

It must also be asked whether the magically-animated man in our example, because he is able to move and speak, creates an impossible hurdle for the fixation requirement. ${ }^{54}$ How he accomplishes these feats may be determinative in proving fixation. If his animation and speech is generated by a fixed program, then he generally satisfies the fixation requirement. ${ }^{55}$ However, if he is created through magic or some other "unfixed" technology, a more detailed analysis is required to determine whether he has the necessary "fixation" be given copyright protection under the Act.

One could argue that his transient nature prevents the magically-animated man in our painting from achieving fixation. However, proof of fixation can be based on three arguments: (1) the painting and the magically-animated man is more than transient or ephemeral; (2) that the painting can be compared to videogames whose software allows for a finite number of results,

\section{${ }^{54} I d$.}

${ }^{55}$ See Midway Mfg Co. v. Artic Int'1, Inc., 547 F. Supp. 999, aff'd, 704 F.2d 1009 (7th Cir. 1982), cert. denied, 464 U.S. 823 (1983) (holding that a fixed program with a finite number of combinations available meets the fixation requirement). See also Stern Electronics Co. v. Kaufman, 669 F.2d 852 (2d Cir. 1982). 
for which case law holds there is the necessary fixation; ${ }^{56}$ and (3) the painting can be compared to comic book and cartoon characters, which are fixed initially, and are considered copyrightable if they achieve a level of development and complexity. ${ }^{57}$

First, the magically-animated man in the painting is not transient- he has substantive form for a substantial period of time, and the overall painting is not ephemeral. Even if the fat lady were transformed into a buff young man, one could argue that she would have existed "long enough" to have achieved fixation. The fat lady's transformation can be analogized to a software program or data residing in the temporary memory of computer. When we write prose on our word processor, or run a word-processing program, even if we never save the document, it has existed in the Random Access Memory (RAM) long enough to have achieved "fixation."58

Second, the painting could be compared to the videogames at issue in Stern Electronics, Inc. v. Kaufman. ${ }^{59}$ In Stern, the Second Circuit found that, while the entire sequence of sights and sounds in a space attack videogame

are different each time the game is played,... many aspects of the sights and the sequence of their appearance remain constant during each play of the game. . . [While] some of these sights and sounds will not be seen and heard during each play of the game. . . [t] he repetitive sequence of a substantial portion of the sights

\footnotetext{
${ }^{56}$ See discussion infra, notes 59 to 60 and accompanying text.

${ }^{57}$ See discussion infra, notes 61 to 69 and accompanying text. One could also draw an analogy between the magically-animated man and a Gumby doll, which, while the basic characteristics do not change, can be manipulated into an infinite number of positions. Each particular pose may meet the fixation requirement.

${ }^{58}$ Advanced Computer Svcs. of Mich., Inc. v. MAI Sys. Corp., 845 F. Supp. 356 (E.D.Va., Alexandria Division 1994) (holding that a computer "program, in the form of electrical impulses in RAM, is adequately "fixed" to qualify as a "copy" for purposes of the Act . . . [A] software program residing in RAM is stable enough to be perceived, reproduced, or otherwise communicated for a period of more than transitory duration.") (internal quotations omitted); see also Stern Electronics, Inc. v. Kaufman, 669 F.2d 852, 855 (2nd Cir. 1982) (holding that the temporary storage of data in the memory of a computer game satisfied "the statutory requirement of a copy in which the work is fixed") (internal quotations omitted).

${ }^{59} 669$ F.2d 852 (2d Cir. 1982).
} 
and sounds of the game qualifies for copyright protection as an audiovisual work. $^{60}$

Using this comparison, one could argue that the magically-animated painting is the same as a videogame, where the characteristics of the game/painting are fixed, but the player can manipulate the situation. The animation via magic could be equated to the artist acting as the videogame player, setting in motion a series of events based on a complex set of magically preprogrammed sights and sounds.

Third, a character in a painting who moves and talks might be seen as similar to a comic book character rather than a purely literary work, such as a novel. Courts have long held a distinction between literary characters described only through words, and those which are also embodied in drawings, such as comic book characters or cartoons. Purely written descriptions of characters rarely enjoy copyright protection outside of the embodied work. In the seminal case of Nichols v. Universal Pictures Corp., ${ }^{61}$ Judge Learned Hand stated that "the less developed the characters, the less they can be copyrighted; that is the penalty an author must bear for marking them to indistinctly."

However, the courts have distinguished between purely literary characters, and those embodied in other media, such as cartoons and comic books, which have an element of visual descriptiveness. In Walt Disney Productions v. Air Pirates, ${ }^{62}$ the Ninth Circuit held that

characters are always limited and always fall into limited patterns. . . .when the author can add a visual image, however, the difficulty is reduced. . . . Put another way, while many literary characters may embody little more than an unprotected idea . . . a comic book character, which has physical as well as conceptual

\footnotetext{
${ }^{60} I d$. at 856.

${ }^{61} 45$ F.2d 119 (1930) cert. denied, 282 US 902 (1931).

${ }^{62} 581$ F.2d 751 (9th Cir. 1979).
} 
qualities, is more likely to contain some unique elements of expression. . . [and] therefore are distinguishable from literary characters ... ${ }^{63}$

Likewise, in Gaiman v. McFarlane, ${ }^{64}$ Judge Posner held, that while the individual elements of a comic book character may not be copyrightable, they may be uniquely combined so that they are drawn, named, and given speech in such a way as to be "sufficiently distinctive [as] to be copyrightable," even when the individual contributions by themselves are not. ${ }^{65}$

Thus, subjects in photographs and paintings who move and speak via magic could be copyrightable as distinct characters, such as those who are clearly defined in a comic book. ${ }^{66}$ Their fixation is not dependent solely on whether they are fixed on the canvas or photographic paper, but may also be achieved through their character development. The Fat Lady portrayed in a painting at the entrance to the Gryffindor Tower has a personality and features unique to her, regardless of where she moves, by magic or through a fixed program. Yet she is not a person - she was originally painted by someone who chose her personality traits and physical features, and is therefore copyrightable just as a character described in a book, play or comic strip would be. Unless the artist chooses, the nurse in the painting in the infirmary will not be found in a miniskirt, nor will the Fat Lady change from her ball gown into a bikini. They

\footnotetext{
${ }^{63} I d$. at 755 . There is a downside to the copyrightability of characters. If the author creates a series of copyrighted stories about the character, then, if the character itself holds a copyright, "to the extent that the character is delineated in the initial work, it passes into the public domain along with that work, and receives no continuing protection from the copyrights in the subsequent works." Burroughs v. Metro-Goldwyn-Mayer, Inc., 683 F.2d 610, 631 (2d Cir. 1982).

${ }^{64} 360$ F.3d 644 (7th Cir. 2004).

${ }^{65}$ Id. at 662. But see Gregory S. Schienke, Comment: The Spawn of Learned Hand-A Reexamination of Copyright Protection and Fictional Characters: How Distinctly Delineated Must the Story Be Told?, 9 MARQ. INTELl. ProP. L. REV. 63 (2005) (analyzing the problems inherent to character protection through copyright).

${ }^{66}$ See generally Gaiman v. McFarlane, 360 F.3d 644 (7th Cir. 2004).
} 
are bound by how the artist contemplated the character. Unlike humans, the magical characters in the paintings will not act outside the bounds that have been set for them by the artist.

For a character to be copyrightable, it should be well-developed and have fixation. If a stand-up comedian creates a well-developed character that appears in thousands of his live shows, but nothing regarding the character is ever written down, the character is not protected by copyright. ${ }^{67}$ Likewise, merely describing a character in a book has been viewed as insufficient to grant copyright protections for the character, even though the book itself is copyrightable. ${ }^{68}$ However, the man in the painting has more substance than the stand-up comedian's character; he was inked onto the canvas; something was "written down." And he has more substance than a literary character in a book. He is most similar to a character developed in a comic book. Neither he nor the painting which embodies him can be copied, and he cannot be used in derivative works by those who do not have rights in his copyright. ${ }^{69}$

Should we conclude that a spell created a predetermined, finite outcome, then this is no different than using a software program that will produce a finite number of images on the computer screen. If, however, the magic spell is a technical means to create a work, such as a printing press may be used to create an infinite number of pamphlets, the magically-animated painting may be copyrightable but for the fixation requirement. Thus, while we may conclude, that as a whole, the painting with the magically-animated man is not copyrightable, aspects, such as characteristics, may be.

\footnotetext{
67 Based on e-mail correspondence with Robert Brauneis, Associate Professor of Law, Co-Director of the Intellectual Property Law Program, and Co-Director of the Dean Dinwoodey Center for Intellectual Property Studies at the George Washington University Law School.

${ }^{68}$ See, e.g. Nichols v. Universal Pictures Corp., 45 F.2d 119 (1930).

${ }^{69}$ See, e.g. Gaiman, 360 F.3d 644; Walt Disney Productions v. Air Pirates, 581 F.2d 751 (9th Cir. 1979).
} 


\section{Final Thoughts}

If we say that the Copyright Act has no answer to the question of whether moving subjects in the photographs and paintings are fixed, because it does not contemplate a world in which there is magic, then the phrase "now known or later developed" "70 would not have been inserted into the text of Section 102. The qualifications for protection of works created with a new technology, with regards to both subject matter and fixation, may already be adequately addressed under current law, and thus not be necessary. ${ }^{71}$ To attempt to create legislation for a technology that is either in its infancy or does not yet exist without a strong public policy interest in doing so is akin to legislating for magic. And it should not be attempted by Muggles. ${ }^{72}$

\footnotetext{
${ }^{70} 17$ U.S.C. $\S 102(a)(2004)$.
}

${ }^{71}$ Cf. Sony Corporation of Am. v. Universal City Studios, Inc., 464 U.S. 417, 431 (1984).

${ }^{72}$ In the Harry Potter universe, a "Muggle" is the term used to refer to a person who does not possess magical powers-a person who is not a witch or wizard. See SORCERER's STONE at 52-53. 